\title{
Nearshore Sand Bars on Western Mediterranean Beaches
}

\author{
Francesca Ribas, Albert Falqués, and Roland Garnier
}

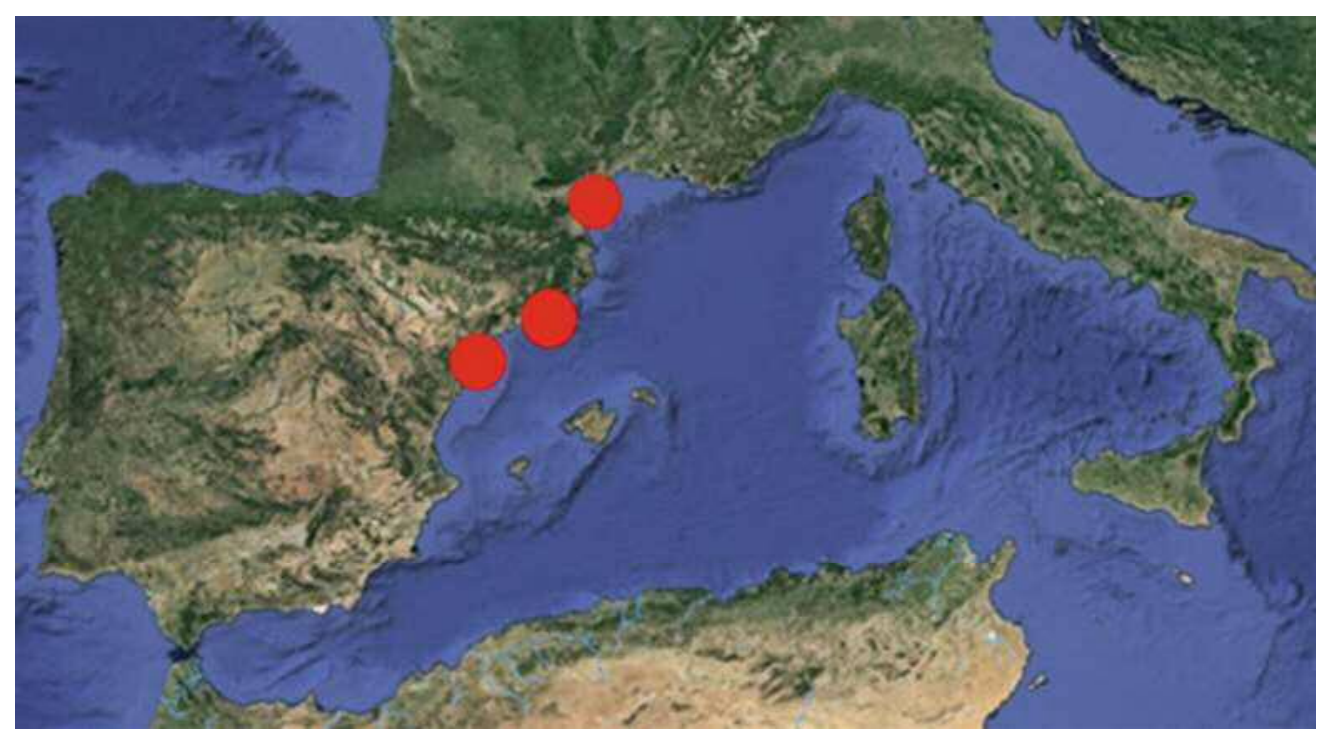

\begin{abstract}
This contribution reviews the existing observations of nearshore sand bars (including shore-parallel straight and crescentic bars, and transverse bars) on western Mediterranean beaches. In general, their morphological characteristics and the dynamic processes they experience do not differ qualitatively from those measured on other coasts. A peculiarity of the bars in western Mediterranean is their slower dynamics due to the milder climate, characterized by short-period waves and long episodes of small waves. During these calm periods, the morphology is arrested because there is no significant sediment transport.
\end{abstract}

\section{Keywords}

Shore-parallel bars - Crescentic bars - Transverse bars - Catalan coast • Gulf of Lions • Sediment transport $\bullet$ Coastal morphodynamics

F. Ribas $(\bowtie) \cdot$ A. Falqués

Department of Physics, Universitat Politècnica de Catalunya,

Barcelona, Spain

e-mail: francesca.ribas@upc.edu

R. Garnier

Environmental Hydraulics Institute (IH Cantabria),

Universidad de Cantabria, Santander, Spain 


\subsection{Introduction}

Nearshore bars are sand deposits with length scales of tens to hundreds of metres and time scales of hours to weeks occurring in the surf zone of sandy beaches (see a detailed description in Ribas et al. 2016). These morphological features have been intensively studied in different parts of the world, but they have only been sporadically surveyed on beaches of the western Mediterranean Sea (Table 14.1).

King and Williams (1949) were pioneers in describing (rather qualitatively) the shore-parallel sand bars (both straight and crescentic) occurring in several open and embayed beaches of the west of Italy (e.g. to the south of Rome and in the Gulf of Salerno), the south of France (e.g. in Les Karantes, in the eastern part of the Gulf of Lions) and Algeria. (The italicized terms throughout the text are the names of the morphological patterns related to nearshore bars described in Ribas et al. 2016.) Other Algerian beaches showing crescentic bars were studied in the 1960s (see reviews by Sonu (1973) and Barusseau and Saint-Guily (1981)). Also, multiple offshore sand bars are a common feature in north-eastern part of Jerba Island, Tunisia (Boczar-Karakiewicz et al. 2001).

Nowadays, most of the research studies focus on the western part of the Gulf of Lions, Languedoc-Roussillon, France (see Sect. 14.2) and the coast of Catalonia, Spain (see Sect. 14.3). Nearshore bars have also been monitored on other beaches of the Spanish coast. Backstrom et al. (2008) studied a double shore-parallel bar system in the southern part of the Velez delta, Andalucía, Spain. They quantified the dynamics during a major eastern ('Levante') storm. The single shore-parallel bar present in Cala Millor, in Mallorca, was monitored monthly by Gómez-Pujol et al. (2011) for eight months. This sandy beach is embayed, with a length of $1700 \mathrm{~m}$. During the monitoring period, characterized by mild wave conditions, a crescentic bar migrated onshore, welded to the upper beach and then flattened under energetic wave conditions.

\subsection{Observations of Nearshore Sand Bars in the Western Gulf of Lions, France}

The western part of the Gulf of Lions (LanguedocRoussillon, France) has been studied in detail by several authors (Barusseau and Saint-Guily 1981; Certain and Barusseau 2005; Gervais et al. 2011; Aleman et al. 2011, 2013, 2015). In particular, Aleman et al. $(2011,2015)$ used a large topo-bathymetric LIDAR survey conducted in summer 2009 along the whole Languedoc-Roussillon coast, from Argelès up to Saintes-Maries-de-la-Mer. This 200-km-long coast consists of quasi-continuous sandy beaches with a welldeveloped double sandbar system. In half of the surveyed area, both shore-parallel bars were shown to switch between the straight and the crescentic configurations, the latter occurring most often in the inner bar. In some parts, the crescentic inner bar was attached to the shore, becoming a system of transverse TBR bars. A limitation of that LIDAR survey is that the bar dynamics could not be described because only one survey was available. Examples of the double bar system near Port-la Nouvelle (southern part of the Gulf of Lions) in 2003 and 2008 are displayed in Fig. 14.1, clearly showing the spatial and temporal variability of the bar configurations. In the northern system, both bars were straight in 2008 (b) but the inner bar was crescentic in 2003 (a). In the southern system, the inner bar was in a transverse TBR bar configuration and the outer one was crescentic in both years, but in 2008 the 3D patterns were less pronounced (c, d). Aleman et al. (2013) evaluated the interannual cross-shore migration of the shore-parallel bars on the LanguedocRoussillon coast, finding net offshore migration with different cycle periods on the different parts of the coast and an absence of net offshore migration on other parts more sheltered.

Certain and Barusseau (2005) had previously described the cross-shore migration (at different time scales) of the bars in the double shore-parallel bar system in Sète (LanguedocRoussillon, France). The bars displayed the standard behaviour of seaward migration during storms and shoreward migration when the energy conditions decreased. The net offshore migration behaviour was triggered by extreme storm events, during which the outer bar moved strongly seaward and degenerated following heavy swell. The inner bar, exposed to the swell, then moved seaward to replace the initial outer bar, and a new inner bar was created at the coast. Finally, Gervais et al. (2011) described the short-term 3D evolution of the crescentic inner bar in Sète during two major storms in winter 2008-2009. Their results evidence the important role of the pre-storm morphology in the final configuration.

\subsection{Observations of Nearshore Sand Bars on Catalan Beaches, Spain}

\subsubsection{Ebro Delta}

A system of low-energy transverse finger bars was surveyed by Falqués (1989) in the inner part of El Trabucador, Ebro delta. The bars are located inside the Alfacs bay, a fetch-limited site affected by waves of low height. The alongshore spacing between bars was measured to be $60 \mathrm{~m}$ on average and the bars were obliquely oriented some $10^{\circ}-$ $40^{\circ}$ (with respect to the shore normal) towards the SW. It is 
Table 14.1 Description of published observations of nearshore sand bars on western Mediterranean beaches (in journals indexed in the Journal Citation Reports)

\begin{tabular}{|c|c|c|c|c|}
\hline References & Sites & Type of bars & Measurements $^{\mathrm{a}}$ & Complementary data \\
\hline $\begin{array}{l}\text { King and Williams } \\
(1949)\end{array}$ & $\begin{array}{l}\text { Beaches of western Italy, } \\
\text { Algeria and southern France }\end{array}$ & $\begin{array}{l}\text { Shore-parallel straight and } \\
\text { crescentic bars }\end{array}$ & $\begin{array}{l}\text { Sporadic '2D surveys' \& } \\
\text { aerial photographs }\end{array}$ & $\begin{array}{l}\text { Dynamics qualitative } \\
\text { Forcing qualitative }\end{array}$ \\
\hline $\begin{array}{l}\text { Barusseau and } \\
\text { Saint-Guily (1981) }\end{array}$ & \multirow{3}{*}{$\begin{array}{l}\text { Several beaches of } \\
\text { Languedoc-Roussillon, } \\
\text { France }\end{array}$} & \multirow{3}{*}{$\begin{array}{l}\text { Double shore-parallel bar } \\
\text { system with } \\
\text { straight/crescentic bars and } \\
\text { TBR bars }\end{array}$} & Aerial photographs & $\begin{array}{l}\text { Dynamics not described } \\
\text { Forcing qualitative }\end{array}$ \\
\hline $\begin{array}{l}\text { Aleman et al. } \\
(2011,2015)\end{array}$ & & & $\begin{array}{l}1 \text { LIDAR ‘3D survey' \& } \\
\text { aerial photographs }\end{array}$ & $\begin{array}{l}\text { Dynamics not described } \\
\text { Forcing quantitative }\end{array}$ \\
\hline $\begin{array}{l}\text { Aleman et al. } \\
(2013)\end{array}$ & & & $\begin{array}{l}\text { '2D surveys' every } 1-2 \text { y for } \\
24 \mathrm{y}\end{array}$ & $\begin{array}{l}\text { Dynamics quantitative } \\
\text { Forcing quantitative }\end{array}$ \\
\hline $\begin{array}{l}\text { Certain and } \\
\text { Barusseau (2005) }\end{array}$ & \multirow{2}{*}{$\begin{array}{l}\text { Sète beach, } \\
\text { Languedoc-Roussillon, } \\
\text { France }\end{array}$} & \multirow{2}{*}{$\begin{array}{l}\text { Double shore-parallel bar } \\
\text { system with straight and } \\
\text { crescentic bars }\end{array}$} & $\begin{array}{l}\text { '2D surveys' for several } \\
\text { years }\end{array}$ & $\begin{array}{l}\text { Dynamics quantitative } \\
\text { Forcing quantitative }\end{array}$ \\
\hline $\begin{array}{l}\text { Gervais et al. } \\
(2011)\end{array}$ & & & $\begin{array}{l}4 \text { '3D surveys', before and } \\
\text { after } 2 \text { major storms }\end{array}$ & $\begin{array}{l}\text { Dynamics quantitative } \\
\text { Forcing quantitative }\end{array}$ \\
\hline $\begin{array}{l}\text { Backstrom et al. } \\
(2008)\end{array}$ & $\begin{array}{l}\text { Velez delta, Andalucía, } \\
\text { Spain }\end{array}$ & Shore-parallel straight bar & $\begin{array}{l}2 \text { '2D surveys', before and } \\
\text { after a major storm }\end{array}$ & $\begin{array}{l}\text { Dynamics quantitative } \\
\text { Forcing quantitative }\end{array}$ \\
\hline $\begin{array}{l}\text { Gómez-Pujol et al. } \\
\text { (2011) }\end{array}$ & $\begin{array}{l}\text { Cala Millor, Mallorca } \\
\text { Balearic Island, Spain }\end{array}$ & $\begin{array}{l}\text { Shore-parallel } \\
\text { straight/crescentic bar and } \\
\text { TBR bars }\end{array}$ & $\begin{array}{l}\text { Monthly '3D surveys' for } \\
8 \text { months }\end{array}$ & $\begin{array}{l}\text { Dynamics quantitative } \\
\text { Forcing quantitative }\end{array}$ \\
\hline Falqués (1989) & $\begin{array}{l}\text { Alfacs Bay, Ebro delta, } \\
\text { Catalonia, Spain }\end{array}$ & $\begin{array}{l}\text { Low-energy transverse } \\
\text { finger bars }\end{array}$ & $\begin{array}{l}1 \text { '3D survey' \& aerial } \\
\text { photographs and maps }\end{array}$ & $\begin{array}{l}\text { Dynamics qualitative } \\
\text { Forcing qualitative }\end{array}$ \\
\hline $\begin{array}{l}\text { Guillén and } \\
\text { Palanques (1993) }\end{array}$ & $\begin{array}{l}\text { Ebro Delta plain, Catalonia, } \\
\text { Spain }\end{array}$ & Shore-parallel straight bars & $\begin{array}{l}\text { '2D surveys' every } 4 \text { months } \\
\text { for } 1 \text { y and } 2 \text { months }\end{array}$ & $\begin{array}{l}\text { Dynamics quantitative } \\
\text { Forcing not described }\end{array}$ \\
\hline Ojeda et al. (2011) & $\begin{array}{l}\text { Barcelona city beaches, } \\
\text { Catalonia, Spain }\end{array}$ & $\begin{array}{l}\text { Shore-parallel } \\
\text { straight/crescentic bar and } \\
\text { TBR bars }\end{array}$ & $\begin{array}{l}4.3 \text { y: hourly video } \\
\text { observations \& annual '3D } \\
\text { surveys' }\end{array}$ & $\begin{array}{l}\text { Dynamics quantitative } \\
\text { Forcing quantitative }\end{array}$ \\
\hline $\begin{array}{l}\text { de Swart et al. } \\
\text { (2016) }\end{array}$ & $\begin{array}{l}\text { Castelldefels beach, } \\
\text { Catalonia, Spain }\end{array}$ & $\begin{array}{l}\text { Double shore-parallel bar } \\
\text { system with } \\
\text { straight/crescentic bars and } \\
\text { TBR bars }\end{array}$ & $\begin{array}{l}4.2 \text { y: hourly video } \\
\text { observations \& '3D surveys' } \\
\text { every } 6 \text { months }\end{array}$ & $\begin{array}{l}\text { Dynamics quantitative } \\
\text { Forcing quantitative }\end{array}$ \\
\hline
\end{tabular}

aTime period and morphologic measurements ('3D surveys' refers to topo-bathymetric surveys when successive profiles are close enough $(<100 \mathrm{~m})$ to show the 3D morphology, and '2D surveys' otherwise)

a quite persistent bar system that can be observed in many of the available aerial photographs of the "Institut Cartogràtic i Geològic de Catalunya" since 1973, as shown in Fig. 14.2. Interestingly, it is nevertheless dynamic since bars are not present in some other photographs.

The whole outer beaches of the Ebro delta were monitored for 1 year and 2 months by Guillén et al. (1993), with 27 cross-shore profiles measured every 4 months. This two-directional drift, open coast displayed a stable system of two shore-parallel bars and a more dynamic inner bar/terrace (an inner terrace and the first outer bar are visible in Fig. 14.2a, b). The bars were not exactly shore-parallel but they displayed a certain obliquity: the distance from the bar crest to the shoreline increases northward and southward from Cape Tortosa, according with the littoral drift direction. The authors suggested this could be due to an alongshore growth of the outer bar during storms. The seasonal migration rate of the bars was also quantified.

\subsubsection{Llobregat Delta (Barcelona and Castelldefels)}

With the advent of video monitoring in the 1990s (see a review in Holman and Haller 2013), the study of nearshore sand bar dynamics made a step forward because data sets with good spatial and temporal resolution became available for long time periods. The first video monitoring station installed on a western Mediterranean beach was that of Barcelona city (northern part of the Llobregat delta). Five cameras located at $142 \mathrm{~m}$ height offer a $180^{\circ}$ view of four of the city's beaches (protected by shore-perpendicular groins) and, since October 2001, the images obtained have been used to study them (Ojeda and Guillén 2006; Ribas et al. 2010; Ojeda et al. 2011). Figure 14.3 shows plan views of two of the beaches, obtained after rectifying and merging the 10-minute exposure images of the five cameras. Ojeda et al. (2011) described the characteristics and dynamics of the 
Fig. 14.1 Double sand bar system near Port-la Nouvelle (a, b, $7 \mathrm{~km}$ north; c, d, $5 \mathrm{~km}$ south), Languedoc-Roussillon, France, in 2003 (a, c) and in 2008 (b, d). The coordinates of the centre of the shorelines are $43^{\circ} 04^{\prime} 27^{\prime \prime} \mathrm{N}-$ $03^{\circ} 05^{\prime} 38^{\prime \prime} \mathrm{E}(\mathbf{a}, \mathbf{b})$ and $42^{\circ} 58^{\prime} 38^{\prime \prime} \mathrm{N}-03^{\circ} 02^{\prime} 54^{\prime \prime} \mathrm{E}(\mathbf{c}$ d). Google Earth images in December 2003 and 2008 (a, c, d, image from NASA; $\mathbf{b}$, image from DigitalGlobe). The morphological configurations of the bars vary in time and space: the inner bar is most often crescentic and the outer bar is most often straight
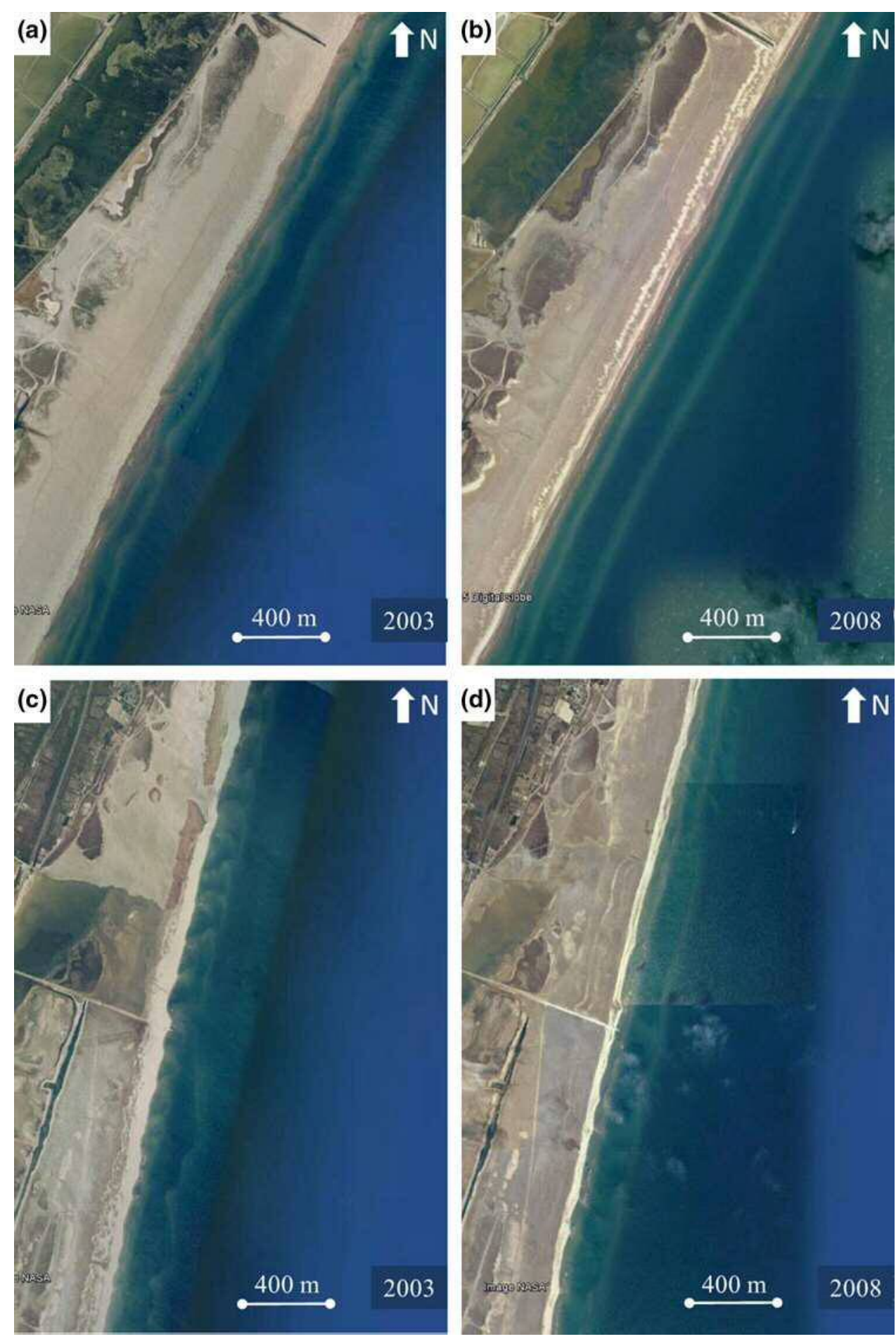

shore-parallel bars on these beaches for 4.3 years. Bogatell (600 m length) displayed a terrace and La Barceloneta (1100 m length) displayed a shore-parallel bar (data obtained from 3D topo-bathymetric surveys, Ribas et al. 2010). The terrace edge of Bogatell and the bar of La Barceloneta switched between a straight configuration during storms (Fig. 14.3a, f), and a crescentic shape configuration
(Fig. 14.3b, g) and a system of transverse TBR bars (Fig. 14.3c-e, h-j) during milder conditions, when the system also migrated slowly onshore (Ojeda et al. 2011). The time scales of the variability of the cross-shore bar position and the 3D morphology were different on the two Barcelona beaches: the smaller terraced-bar at Bogatell beach underwent a larger number of changes. An arrest of the beach 

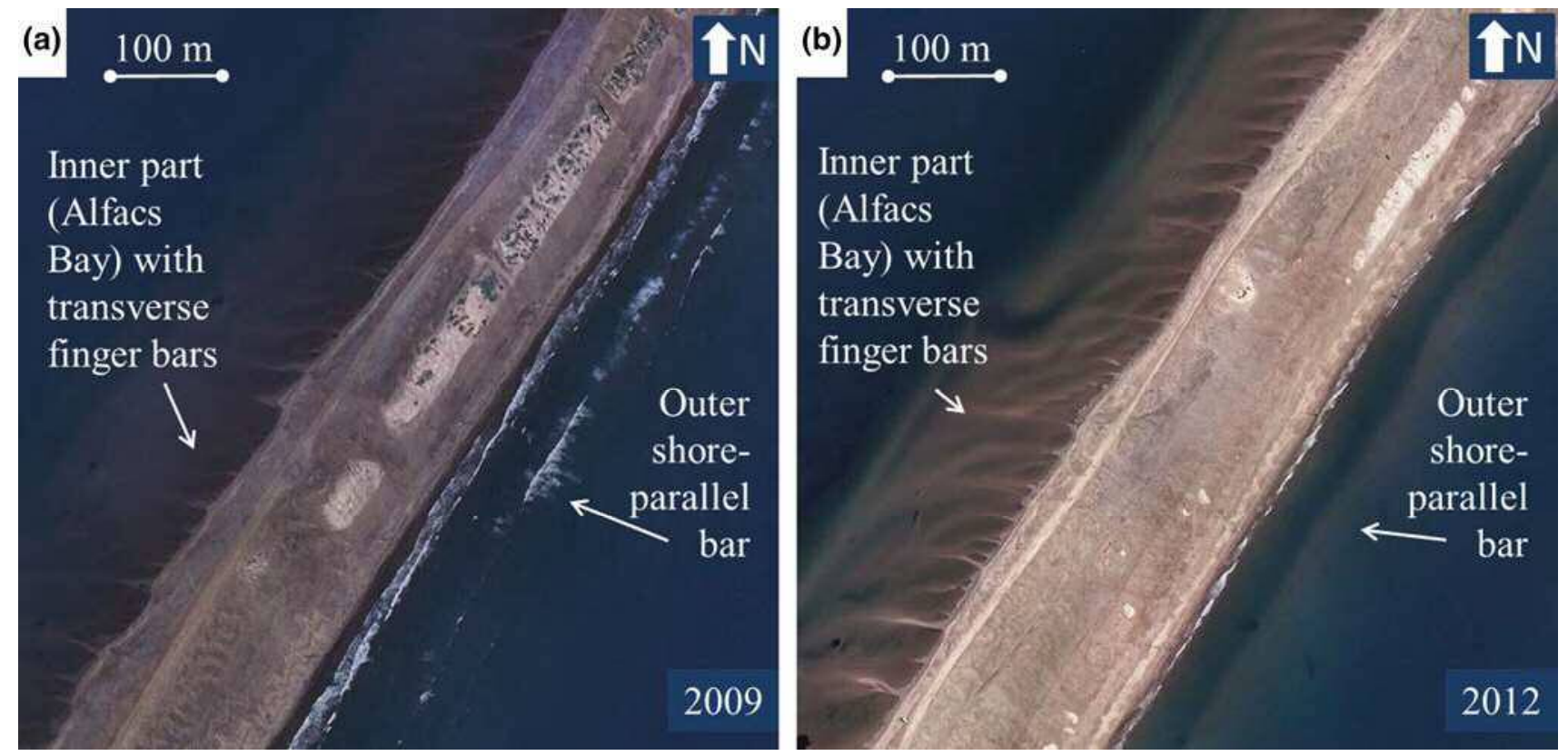

Fig. 14.2 Low-energy transverse finger bars in the inner part of El Trabucador, Ebro Delta, and shore-parallel straight bars in the outer part in 2009 (a) and 2012 (b). The coordinates of the centre of the image are $40^{\circ} 36^{\prime} 21^{\prime \prime} \mathrm{N}-0^{\circ} 43^{\prime} 21^{\prime \prime} \mathrm{E}$. Orthophotos from the "Institut Cartogràfic i Geològic de Catalunya"

configuration at these beaches typically occurs during long periods, mostly associated with the long summer season typical of Mediterranean wave conditions. On the interannual time scale, Barcelona bars showed no net offshore migration trend during the study period.

A video monitoring station was more recently installed atop a 30-m-high structure on Castelldefels open beach, in the southern part of the Llobregat delta, $20 \mathrm{~km}$ south of Barcelona, and has been providing images since October 2010. These images, together with 3D topo-bathymetric surveys, are being used to study the dynamics of the double shore-parallel sand bar system over four years and three months (de Swart et al. 2016). The outer bar was always straight and the inner bar was also approximately straight in 2011-2012 but it behaved dynamically in 2013-2014, varying between a straight and a crescentic configuration, and often welding to the beach as transverse TBR bars. The straightening of crescentic bars was shown to be related to oblique waves. Figure 14.4 shows the typical stages during a crescentic bar event: initial straight bar (Fig. 14.4a), crescentic bar of small amplitude (Fig. 14.4b), crescentic bar of large amplitude with megacusps (Fig. 14.4c), and bar straightening with a complex configuration in the inner surf zone after a second storm with oblique wave incidence (Fig. 14.4d). This beach also displays sporadically medium- energy transverse finger bars (Fig. 14.4e), which are attached to the shoreline within the horns of the crescentic inner bar.

\subsection{Summary and Comparison with Nearshore Bars on Other Coasts}

Nearshore bars appear on sandy western Mediterranean beaches, both open and embayed, as often as on other microto mesotidal coasts but they have been monitored much less intensively. As occurs in other parts of the world (see Ribas et al. 2016), on coasts with fine to medium sediment the profile is mild and two or three shore-parallel bars can occur (southern part of the Gulf of Lions, the Velez delta, the Ebro Delta plain and Castelldefels). On more sheltered open beaches with medium to coarse sediment, the profile is steeper and only one shore-parallel bar appears (Barcelona and Cala Millor, Spain). In a fetch-limited environment with a very mild profile, low-energy transverse finger bars are quite persistent features (Alfacs bay, Spain). The morphological characteristics of the bars on western Mediterranean beaches and their dynamic processes do not differ qualitatively from those measured at other sites. The fact that Mediterranean coasts have a minimum tidal range (of a few 

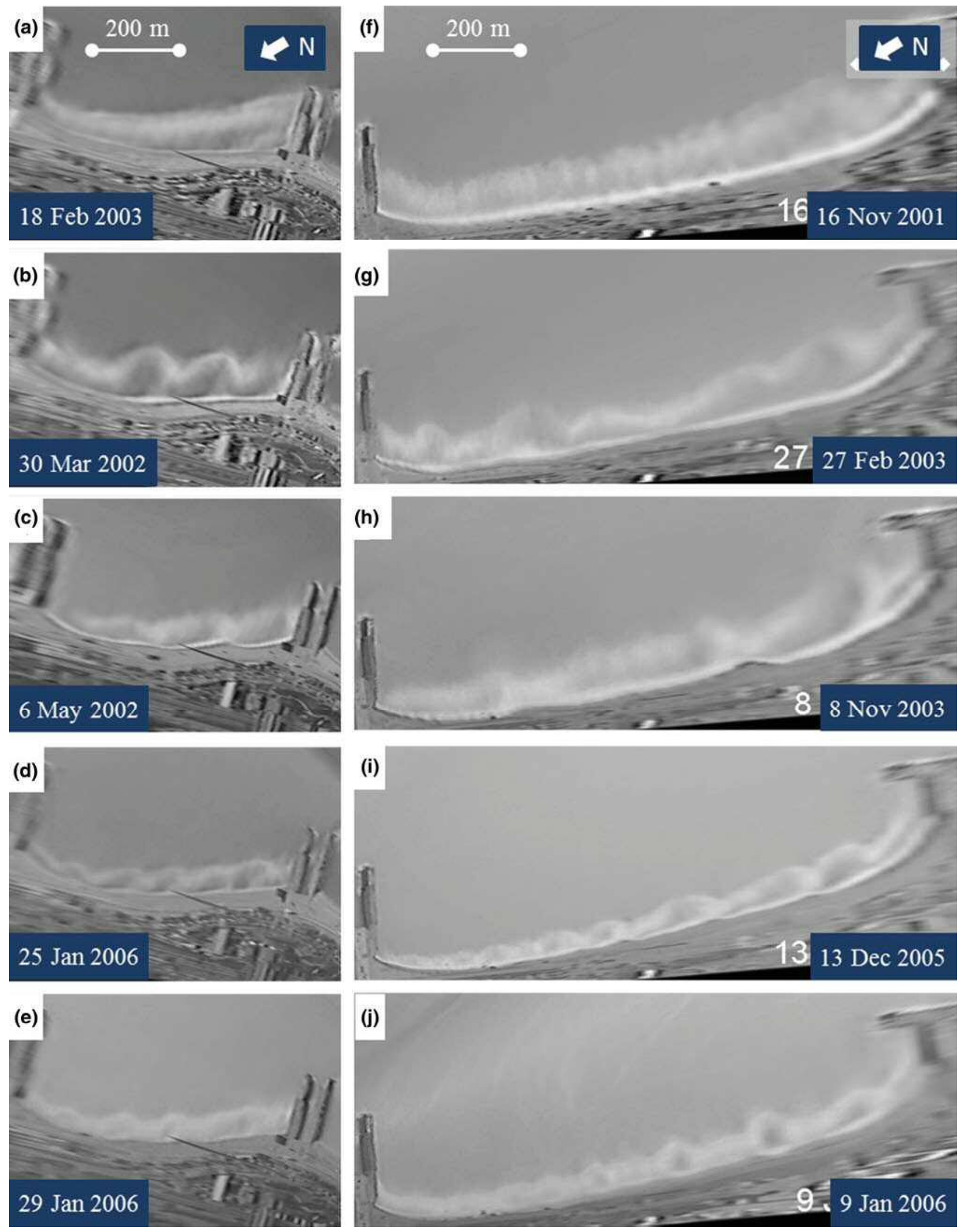

Fig. 14.3 Shore-parallel bars of Barcelona city beaches studied by Ojeda et al. (2011): Bogatell (a-e) and La Barceloneta (f-j). The plan views of the beach are created from time-averaged video-images, where the white zones indicate bar presence due to preferential wave breaking on the shallows. The terrace edge in Bogatell and the bar in La Barceloneta switch between different configurations. The coastline is at the bottom. The coordinates of the centre of the shoreline are $41^{\circ} 23^{\prime} 39^{\prime \prime} \mathrm{N}-2^{\circ} 12^{\prime} 24^{\prime \prime} \mathrm{E}(\mathbf{a}-\mathbf{e})$ and $41^{\circ} 22^{\prime} 32.72^{\prime \prime} \mathrm{N}-02^{\circ} 11^{\prime} 28.11^{\prime \prime} \mathrm{E}$ (f-j). Reprinted from Ojeda et al. (2011), with permission from Elsevier 
tens of centimetres) has not so far been shown to produce any specific morphologic characteristics.

As occurs on other coasts (Ribas et al. 2016), shore-parallel bars experience a fast offshore migration and become straight during storms, to subsequently migrate onshore more slowly during post-storm conditions. During the latter process, they gradually change to a crescentic shape that eventually welds to the beach, becoming a TBR transverse bar system. However, the bars in the western Mediterranean experience slower dynamic processes due to the milder climate, with short-period waves and long episodes of small waves, during which the morphology is arrested because the wave energy is too low to cause significant sediment transport (Certain and Barusseau 2005; Ojeda et al. 2011; Gómez-Pujol et al. 2011; de Swart et al. 2016). Recent data from bars on western Mediterranean beaches confirm the important role of oblique wave incidence in straightening crescentic bars (Álvarez-Ellacuría et al. 2012; de Swart et al. 2016). Interannual net offshore migration has been reported on open beaches (Certain et al. 2005; Aleman et al. 2013) but not on more protected, embayed beaches (Ojeda et al. 2011; Aleman et al. 2013), in agreement with the available literature on other coasts (Ribas et al. 2016). Low-energy transverse finger bars observed in the inner part of the Ebro delta (Falqués 1989) and medium-energy transverse finger bars observed in Castelldefels (Fig. 14.4e) have not been analysed quantitatively but their morphological characteristics are similar to those monitored on other coasts.
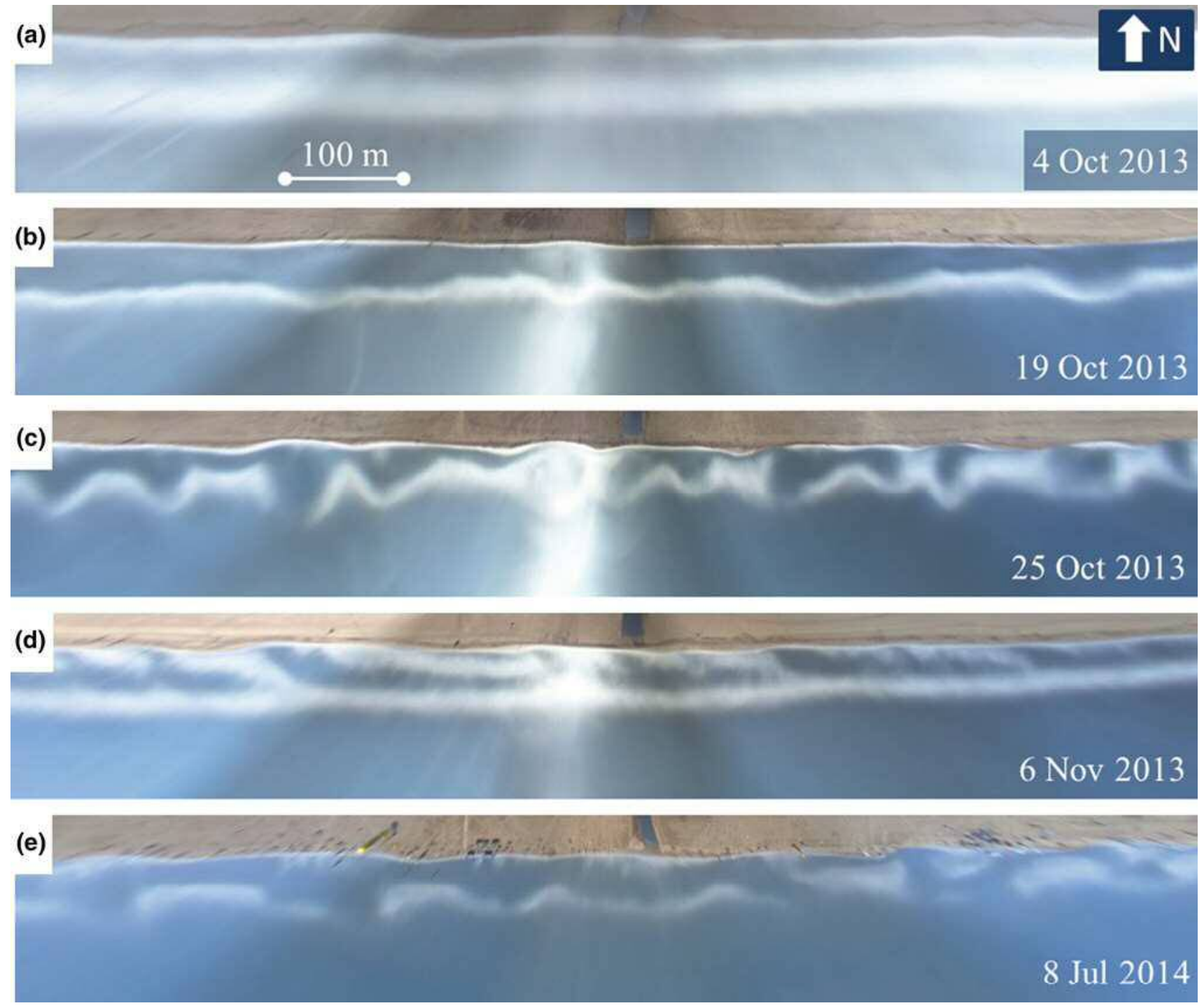

Fig. 14.4 Shore-parallel inner bar of Castelldefels, Catalonia, Spain, switching between different configurations during a crescentic bar event (ad). This beach also displays sporadically medium-energy transverse finger bars attached to the shoreline (e). The coastline is at the top. The coordinates of the centre of the shoreline are $41^{\circ} 15^{\prime} 50^{\prime \prime} \mathrm{N}-1^{\circ} 59^{\prime} 30^{\prime \prime} \mathrm{E}$ 
Acknowledgments This research has been funded by the Spanish government through the research projects CTM2012-35398 (cofunded by FEDER, U.E.) and CTM2015-66225-C2-1-P (MINECO/FEDER).

\section{References}

Aleman, N., N. Robin, R. Certain, E.J. Anthony and J.-P. Barusseau (2015). Longshore variability of beach states and bar types in a microtidal, storm-influenced, low-energy environment, Geomorphology, 241, 175-191, doi:10.1016/j.geomorph.2015.03.029.

Aleman, N., N. Robin, R. Certain, J.-P. Barusseau and M. Gervais (2013). Net offshore bar migration variability at a regional scale: inter-site comparison (Languedoc-Roussillon, France), J. Coast. Res. (SI65), 1715-1720, doi:10.2112/SI65-290.1.

Aleman, N., N. Robin, R. Certain, C. Vanroye, J.-P. Barusseau and F. Bouchette (2011). Typology of nearshore bars in the Gulf of Lions (France) using LIDAR technology, J. Coastal Res., SI64, 721-725.

Álvarez-Ellacuría, A., A. Orfila, L. Gómez-Pujol, and J. Tintoré (2012). Intermediate states transitions in a low microtidal beach, in Coastal Eng. 2012, Poster.

Backstrom, J.T., D.W.T. Jackson, J.A.G. Cooper, and G.C. Malvárez (2008). Storm-driven shoreface morphodynamics on a low-wave energy delta: the role of nearshore topography and shoreline orientation, J. Coastal Res., 24(6), 1379-1387, doi:10.2112/07-0926.1.

Barusseau, J.-P., and B. Saint-Guily (1981). Disposition, caractères et formation des barres d'avant-côte festonnées du Golfe du Lion. Oceanologica acta, 4(3), 297-304.

Boczar-Karakiewicz, B., W. Romanczyk, B. Long and J. L. Bona (2001). Nourishment of a barred nearshore: Jerba, Tunisia, AGU Fall Meeting 2001, abstract \#OS31B-0419.

Certain, R., and J.-P. Barusseau (2005). Conceptual modeling of sand bars morpho-dynamics for a microtidal beach (Sète, France). Bull. Soc. Géol. Fr., 176 (4), 343-354, doi:10.2113/176.4.343.

de Swart, R.L., F. Ribas, G. Ruessink, R. Garnier, G. Simarro and J. Guillén (2016). Characteristics and dynamics of crescentic bar events in an open tideless double-barred beach, in preparation.
Falqués, A. (1989). Formación de topografía rítmica en el Delta del Ebro, Revista de Geofísica, 45(2), 143-156.

Gervais, M., Y. Balouin, J. Thiebot, R. Certain, R. Bélon, R. Pedreros, N. Robin and S. Berne (2011). Morphodynamic evolution of nearshore bars in response to winter storms (Lido de Sète, NW Mediterranean), J. Coastal Res., SI64, 1855-1860.

Gómez-Pujol, L., A. Orfila, A. Álvarez-Ellacuría and J. Tintoré (2011). Controls on sediment dynamics and medium-term morphological change in a barred microtidal beach (Cala Millor, Mallorca, Western Mediterranean), Geomorphology, 132, 87-98, doi:10.1016/j. geomorph.2011.04.026.

Guillén, J., and A. Palanques (1993). Longshore bar and trough systems in a microtidal, storm-wave dominated coast: The Ebro Delta (Northwestern Mediterranean), Mar. Geol., 115, 239-252, doi: 10. 1016/0025-3227(93)90053-X.

Holman, R.A., and Merrick C. Haller (2013). Remote Sensing of the Nearshore. Annu. Rev. Mar. Sci., 5, 95-113, doi:10.1146/annurevmarine-121211-172408.

King, C. A. M., and W. W. Williams (1949). The formation and movement of sand bars by wave action, The Geographical J., 113, 70-85, doi:10.2307/1788907.

Ojeda, E., and J. Guillén (2006). Monitoring beach nourishment based on detailed observations with video measurements. J. Coast. Res. SI 48, 100-106.

Ojeda, E., J. Guillén and F. Ribas (2011). Dynamics of single-barred embayed beaches, Mar. Geol., 280, 76-90, doi:10.1016/j.margeo. 2010.12.002.

Ribas, F., A. Falqués and R. Garnier (2016). Nearshore sand bars, in Atlas of Bedforms in the Western Mediterranean, ch. 13, Springer, ISBN: 978-3-319-33940-5.

Ribas, F., E. Ojeda, T. Price and J. Guillén (2010). Assessing the suitability of video imaging for studying the dynamics of nearshore sandbars in tideless beaches. IEEE Trans. Geosci. Remote Sens. 48 (6), 2482-2497, doi:10.1109/TGRS.2009.2039576.

Sonu, C. J. (1973). Three-dimensional beach changes. The Journal of Geology, 42-64. 